DOI: https://doi.org/10.24127/ajpm.v10i1.2812

\title{
PENGARUH PROBLEM BASED LEARNING TERHADAP KEMAMPUAN PEMECAHAN MASALAH MATEMATIS DITINJAU DARI GENDER DAN LEVEL SEKOLAH
}

\author{
Yerizon $^{1}$, Putri Wahyuni ${ }^{2}$, Ahmad Fauzan ${ }^{3}$ \\ ${ }^{1,2}, 3$ Universitas Negeri Padang, Padang, Indonesia \\ *Corresponding author. Jl. Prof. Dr. Hamka Air Tawar Padang, Sumatera Barat, Indonesia \\ E-mail: $\quad y$ yerizon@fmipa.unp.ac.id $\left.{ }^{1 *}\right)$ \\ wahyunip377@gmail.com ${ }^{2)}$ \\ ahmad.zan66@yahoo.com $^{3)}$
}

Received 18 May 2020; Received in revised form 12 March 2021; Accepted 29 March 2021

\begin{abstract}
Abstrak
Penelitian ini bertujuan untuk mengetahui perberdaan kemampuan pemecahan masalah matematis peserta didik yang memperoleh pembelajaran model Problem Based Learning (PBL) dengan siswa yang menggunakan model pembelajaran konvensional yang ditinjau dari gender (laki-laki dan perempuan) dan level sekolah (tinggi, sedang, rendah) di MTsN Kabupaten Tanah Datar. Jenis peneltian adalah eksperimen dan desain penelitian yang digunakan Randomized Pretest-Posttest Control Group Design dengan variabel bebas model PBL dan konvensional, variabel terikat adalah kemampuan pemecahan masalah matematis dan variabel moderator adalah gender dan level sekolah dengan jumlah sampel sebanyak 146 siswa. Teknik pengolahan data dengan menggunakan uji-t, uji-U dan uji ANOVA dua arah. Hasil penelitian ini menunjukkan bahwa: (1) Kemampuan pemecahan masalah matematis siswa yang belajar dengan model PBL lebih tinggi dibandingkan dengan yang belajar dengan model konvensional di sekolah level tinggi, sedang dan rendah. (2) Kemampuan pemecahan masalah matematis siswa laki-laki dan perempuan yang belajar dengan model PBL lebih tinggi dibandingkan dengan yang belajar dengan model konvensional.(3) Kemampuan pemecahan masalah matematis siswa perempuan lebih tinggi dibandingkan laki-laki (4) Tidak terdapat interaksi antara model pembelajaran dan gender dalam mempengaruhi kemampuan pemecahan masalah matematis siswa. (5) Tidak terdapat interaksi antara model pembelajaran dan level sekolah dalam mempengaruhi kemampuan pemecahan masalah matematis siswa.
\end{abstract}

Kata kunci: Gender; kemampuan pemecahan masalah matematis; level sekolah; problem based learning.

\begin{abstract}
This study aims to determine the difference in mathematical problem-solving abilities of students who obtain Problem Based Learning (PBL) learning models with students who use conventional learning models in terms of gender (male and female) and school level (high, medium, low) in MTsN Tanah Datar District. This type of research is the experimental and research design used by the Randomized Pretest-Posttest Control Group Design with independent variables PBL and conventional models, the dependent variable is the ability to solve mathematical problems and the moderator variable is gender and school level with a total sample of 146 students. Data processing techniques using t-test, U-test and two-way ANOVA test. The results of this study indicate that: (1) The mathematical problem-solving ability of students who learn with PBL models is higher than those who learn with conventional models in high, medium and low level schools. (2) Mathematical problem solving ability of male and female students learning with PBL models is higher than those learning with conventional models. (3) Mathematical problem solving abilities of female students are higher than male students (4) There is no interaction between learning models and gender in influencing students' mathematical problem solving abilities. (5) There is no interaction between learning models and school level in influencing students' mathematical problem solving abilities.
\end{abstract}

Keywords: Gender; mathematical problem solving ability; school level; problem based learning.

This is an open access article under the Creative Commons Attribution 4.0 International License 
DOI: https://doi.org/10.24127/ajpm.v10i1.2812

\section{PENDAHULUAN}

Kemampuan pemecahan masalah merupakan bagian yang penting dalam kurikulum pelajaran matematika. Pemecahan masalah mengandung arti mencari cara, metode atau pendekatan penyelesaian melalui beberapa kegiatan antara lain: mengamati, memahami, mencoba, menduga dan menemukan dan meninjau kembali (Hendriana, 2018). Namun kenyataannya di lapangan menunjukkan bahwa kegiatan pemecahan masalah dalam proses pembelajaran matematika belum dijadikan sebagai kegiatan utama. Padahal keterampilan pemecahan masalah yang berkaitan dengan dunia nyata dapat diintegrasikan untuk menyelesaikan persoalan dan persaingan di dunia nyata pula.

Fakta menunjukkan bahwa rendahnya kemampuan matematis siswa indonesia khususnya siswa SMP masih belum memuaskan. Hal ini dapat dilihat dari hasil Program for International Students Asessement (PISA) terbaru tahun 2015 lebih memperlihatkan lagi, Indonesia berada diperingkat ke-63 dari 69 negara dan Trends in International Mathematics and Science Study (TIMSS) tahun 2015 yang mendapatkan Indonesia diperingkat ke-45 dari 50 negara. Rendahnya kemampuan matematis siswa perlu mendapatkan perhatian yang serius dari semua kalangan di sekolah, terutama guru matematika. Rendahnya kemampuan pemecahan masalah matematis siswa selain dilihat dari hasil survei TIMSS, PISA dan beberapa penelitian juga terlihat ketika diberikan soal kepada siswa kelas VIII MTsN Kabupaten Tanah Datar. Berdasarkan lembar jawaban siswa dapat dilihat bahwa siswa belum mampu mengerjakan soal berbentuk pemecahan masalah dengan benar. Pertama, siswa belum mengidentifikasi masalah, Kedua, siswa belum mampu merumuskan masalah matematika atau menyusun model matematika, dalam merumuskan masalah ini siswa harus mendapatkan data dari masalah tersebut dan yang Ketiga, siswa tidak mampu menerapkan strategi untuk menyelesaikan masalah karena strategi yang digunakan siswa dalam menyelesaikan masalah tersebut tidak tepat. Beberapa penelitian lainnya juga menyatakan hal yang serupa tentang rendahnya kemampuan peserta didik dalam memecahkan masalah matematis seperti penelitian oleh (Eviyanti, Surya, Syahputra, \& Simbolon, 2017), (Darma, Candiasa, Sadia, \& Dantes, 2018), dan (Febriana, Yusri, \& Delyana, 2020).

Banyak alasan terjadinya kegagalan pada siswa yang ditemukan oleh observer yaitu pembelajaran yang terjadi masih bersifat teacher center. Kemampuan pemecahan masalah siswa yaitu kesalahan dalam mengintrepretasikan soal karena kurang memahami masalah yang diajukan. (Murtiyasa \& Wulandari, 2020). Kesalahan lain yang ditemukan oleh Cruz (Dela Cruz \& Lapinid, 2014) dalam tulisannya adalah penggunaan operasi yang salah, kecerobohan dan nilai-nilai yang saling tertukar. Guru berperan lebih aktif selama proses pembelajaran, kemudian dengan metode mengajar kovensional yang digunakan guru memperkecil kemungkinan siswa untuk terlibat aktif dalam bertanya, menjawab pertanyaan, mengeluarkan pendapat, dan berdiskusi dengan teman lain. Siswa tidak mampu menyelesaikan soal jika berbeda dengan yang dicontohkan oleh guru. Kenyataan yang terjadi masih belum sesuai dengan tuntutan proses pembelajaran sesuai dengan kurikulum 2013. Hal tersebut 
berdasarkan hasil observasi di MTsN Tanah Datar.

Berdasarkan Permendikbud Nomor 65 Tahun 2013 Tentang Standar Proses, untuk mendorong kemampuan siswa untuk menghasilkan karya kontekstual, baik individual maupun kelompok maka sangat disarankan menggunakan pendekatan pembelajaran yang menghasilkan karya berbasis pemecahan masalah. Oleh karena itu, penulis memilih model pembelajaran PBL sebagai salah satu alternatif model pembelajaran matematika yang sesuai dengan kurikulum 2013 dan diasumsikan mampu memecahkan permasalahan yang terjadi di MTsN seKabupaten Tanah Datar. Model pembelajaran PBL dianggap dapat meningkatkan kemampuan pemecahan masalah matematis siswa, diantaranya seperti yang ditemukan oleh Sari dalam tulisannya pembelajaran matematika berbasis masalah dapat meningkatkan kemampuan pemecahan masalah matematis siswa. Perbedaan penelitian yang dilakukan oleh Sari dan yang akan dilakukan adalah level sekolah. Didukung oleh pernyataan (Darmawan, 2018) bahwa siswa merasa tertarik ketika guru menerapkan model PBL. Senada dengan itu Rusman menyatakan pembelajaran berbasis masalah mengantarkan siswa memahami konsep dan menyiapkan situasi dengan pokok bahasan yang diajarkan.

Faktor lain selain model PBL yang dapat mempengaruhi kemampuan pemecahan masalah matematis siswa adalah gender. Perbedaan gender tentu menyebabkan perbedaan fisiologi dan memengaruhi perbedaan psikologis dalam belajar. Menurut Eisenberg, Martin dan Fabes adanya temuan yang beragam dalam penelitian soal kemampuan matematika. Dalam beberapa analisis, anak laki-laki lebih bagus dalam matematika (Santrock, 2015). Berdasarkan penelitian lainnya juga ditemukan oleh Ajai (Ajai \& Imoko, 2015) yaitu laki-laki secara konsisten melaporkan persepsi yang sedikit lebih positif dari lingkungan kelas dibandingkan dengan perempuan. Pentingnya penelitian tentang gender ini karena pada kanyataannya dilapangan berdasarkan data nilai semester siswa dan hasil wawancara bersama Guru matematika, ditemukan prestasi belajar ataupun nilai matematika siswa perempuan lebih baik daripada laki-laki, hal ini bertentangan dengan teori dan hasil penelitian yang ditemukan bahwa seharusnya kemampuan matematika laki-laki lebih baik daripada perempuan.

Upaya untuk meningkatkan kemampuan pemecahan masalah matematis siswa dengan model pembelajaran PBL selain ditinjau dari gender, perlu juga diperhatikan faktor level sekolah, dimana menurut Mumun (Maharani, Darhim, Sabandar, \& Herman, 2018) dalam menumbuhkembangkan daya dan disposisi matematis siswa perlu juga diperhatikan faktor level sekolah, yaitu sekolah yang mempunyai level baik, sekolah yang mempunyai level sedang dan sekolah yang mempunyai level rendah. Senada dengan itu penelitian yang dilakukan oleh Nufus (Nufus, 2017) menyatakan terdapat interaksi pembelajaran dan level sekolah terhadap kemampuan matematis siswa serta di sekolah level rendah hasil belajar siswa di kelas kontrol lebih baik daripada kelas eksperimen dan juga ditemukan tidak terdapat perbedaan yang signifikan untuk level sekolah sedang dan rendah. Fachrurazi (Fachrurazi, 2011) menunjukkan bahwa siswa dari sekolah level tinggi memperoleh peningkatan yang lebih baik dibandingkan siswa yang berasal 
dari level sedang dan kurang dan siswa dari level sedang lebih baik dari level kurang. Maharani (Maharani et al., 2018) menyatakan bahwa terdapat perbedaan kemampuan disposisi matematis pada sekolah level sekolah sedang dan rendah.Pentingnya penelitian tentang level sekolah ini dilakukan karena seharusnya hasil belajar siswa dikelas eksperimen lebih baik daripada kelas kontrol. Hal ini juga bertentangan dengan teori bahwa seharusnya level sekolah sedang lebih baik daripada level sekolah rendah.

Pada saat ini akan diteliti model PBL pada kelas VIII MTsN materi lingkaran dan pengaruhnya pada kemampuan pemecahan masalah matematis siswa MTsN Kabupaten Tanah Datardan ditinjau dari gender dan level sekolah. Berdasarkan uraian diatas, maka tujuan dari penelitian ini adalah untuk melihat ada atau tidaknya pengaruh Model Pembelajaran PBL
Terhadap Kemampuan Pemecahan Masalah dan Disposisi Matematis Siswa Ditinjau dari Gender dan Level Sekolah di MTsN Kabupaten Tanah Datar.

\section{METODE PENELITIAN}

Penelitian ini merupakan penelitian eksperimen yang menenmpatkan kemampuan pemecahan masalah matematis sebagai variabel terikat, model pembelajaran sebagai variabel bebas dan gender serta level sekolah sebagi variabel moderator. Model pembelajaran yang diterapkan dalam penelitian ini adalah model PBL (X1) sebagai kelas eksperimen dan konvensional (X2) sebagai kelas kontrolnya, sedangkan untuk variabel gender diklasifikasikan menjadi lakilaki (A1) dan perempuan (A2) dan level sekolah diklasifikasikan menjadi dua yaitu level sekolah tinggi (B1), sedang (B2) dan rendah (B3).

Tabel 1. Desain penelitian.

\begin{tabular}{|c|c|c|c|}
\hline \multirow[t]{2}{*}{ Varibel Modertor } & \multirow[t]{2}{*}{ Klasifikasi } & \multicolumn{2}{|c|}{$\begin{array}{c}\text { Kemampuan Pemecahan Masalah } \\
\text { Matematis }\left(Y_{1}\right)\end{array}$} \\
\hline & & Eksperimen $\left(\mathrm{X}_{1}\right)$ & Kontrol $\left(\mathrm{X}_{2}\right)$ \\
\hline \multirow[t]{2}{*}{ Gender } & Laki-laki $\left(\mathrm{A}_{1}\right)$ & $\mathrm{X}_{1} \mathrm{Y}_{1} \mathrm{~A}_{1}$ & $\mathrm{X}_{2} \mathrm{Y}_{1} \mathrm{~A}_{1}$ \\
\hline & Perempuan $\left(\mathrm{A}_{2}\right)$ & $\mathrm{X}_{1} \mathrm{Y}_{1} \mathrm{~A}_{2}$ & $\mathrm{X}_{2} \mathrm{Y}_{1} \mathrm{~A}_{2}$ \\
\hline \multirow{3}{*}{ Level Sekolah } & Tinggi $\left(B_{1}\right)$ & $\mathrm{X}_{1} \mathrm{Y}_{1} \mathrm{~B}_{1}$ & $\mathrm{X}_{2} \mathrm{Y}_{1} \mathrm{~B}_{1}$ \\
\hline & Sedang $\left(\mathrm{B}_{2}\right)$ & $\mathrm{X}_{1} \mathrm{Y}_{1} \mathrm{~B}_{2}$ & $\mathrm{X}_{2} \mathrm{Y}_{1} \mathrm{~B}_{2}$ \\
\hline & Rendah $\left(\mathrm{B}_{3}\right)$ & $\mathrm{X}_{1} \mathrm{Y}_{1} \mathrm{~B}_{3}$ & $\mathrm{X}_{2} \mathrm{Y}_{1} \mathrm{~B}_{3}$ \\
\hline
\end{tabular}

Penelitian dilakukan pada siswa kelas VIII MTsN Kabupaten Tanah Datar. Peneltian dilakukan pada semester genap tahun ajaran 2019/2020. Instrumen kemampuan pemecahan masalah matematis siswa menggunakan tes essay berjumlah 5 butir soal yang telah diuji validasinya. Untuk menggolongkan level sekolah dilakukan dengan (1) menjumlahkan seluruh skor nilai UN masing-masing sekolah, (2) mencari nilai rata-rata (mean) dan simpangan baku (SD), (3) menentukan batas-batas kelompok untuk level sekolah tinggi, sedang dan rendah, kemudian dari masing-masing sekolah sampel dipilih kelas eksperimen dan kontrol dengan cara purposive sampling. Data yang diperoleh dianalisis menggunakan aplikasi SPSS, analisis yang dilakukan yaitu statistik deskriptif, uji persyaratan data meliputi uji normalitas dan uji homogenitas, selanjutnya diuji hipotesis dengan uji-t dan ANOVA dua arah. 
DOI: https://doi.org/10.24127/ajpm.v10i1.2812

\section{HASIL DAN PEMBAHASAN}

Pada penelitian ini dilihat tingkat kemampuan pemecahan masalah matematis siswa dari sekolah level tinggi, sedang dan rendah serta dari gender laki-laki dan perempuan. Hasil perhitungan skor $\mathrm{N}$-gain kemampuan pemecahan masalah siswa tersebut dijabarkan seperti pada Tabel 1 .

Tabel 1. Statistik deskrpstif skor $N$-Gain kemampuan pemacahan masalah matematis siswa berdasarkan level sekolah dan gender.

\begin{tabular}{ccccccccccc}
\hline & \multicolumn{2}{c}{ Tinggi } & \multicolumn{2}{c}{ Sedang } & \multicolumn{2}{c}{ Rendah } & \multicolumn{2}{c}{ Laki-laki } & \multicolumn{2}{c}{ Perempuan } \\
\hline & $\begin{array}{c}\text { Eks } \\
\mathbf{X}_{\mathbf{1}}\end{array}$ & $\begin{array}{c}\text { Kontrol } \\
\left(\mathbf{X}_{\mathbf{2}}\right)\end{array}$ & $\begin{array}{c}\text { Eks } \\
\left(\mathbf{X}_{\mathbf{1}}\right)\end{array}$ & $\begin{array}{c}\text { Kontrol } \\
\left(\mathbf{X}_{\mathbf{2}}\right)\end{array}$ & $\begin{array}{c}\text { Eks } \\
\left(\mathbf{X}_{\mathbf{1}}\right)\end{array}$ & $\begin{array}{c}\text { Kontrol } \\
\left(\mathbf{X}_{\mathbf{2}}\right)\end{array}$ & $\begin{array}{c}\text { Eks } \\
\left(\mathbf{X}_{\mathbf{1}}\right)\end{array}$ & $\begin{array}{c}\text { Kontrol } \\
\left(\mathbf{X}_{\mathbf{2}}\right)\end{array}$ & $\begin{array}{c}\text { Eks } \\
\left(\mathbf{X}_{\mathbf{1}}\right)\end{array}$ & $\begin{array}{c}\text { Kontrol } \\
\left(\mathbf{X}_{\mathbf{2}}\right)\end{array}$ \\
\hline $\mathrm{N}$ & 30 & 29 & 25 & 23 & 21 & 18 & 37 & 33 & 39 & 37 \\
\hline Min & 0,33 & 0,17 & 0,14 & 0,21 & 0,22 & 0,10 & 0,14 & 0,10 & 0,24 & 0,14 \\
\hline Max & 0,90 & 0,76 & 0,92 & 0,67 & 0,68 & 0,31 & 0,77 & 0,76 & 0,92 & 0,67 \\
\hline $\bar{x}$ & 0,58 & 0,40 & 0,58 & 0,36 & 0,41 & 0,21 & 0,47 & 0,33 & 0,66 & 0,35 \\
\hline
\end{tabular}

Hasil tes kemampuan pemecahan masalah matematis siswa yang diberikan pada kelas sampel menunujukkan bahwa rata-rata kelas eksperimen lebih tinggi daripada kelas kontrol. Simpangan baku kelas eksperimen juga lebih tinggi daripada kelas kontrol. Pada penelitian ini dilihat tingkat kemampuan pemecahan masalah matematis siswa di MTsN Kabupaten Tanah Datar, dari sekolah level tinggi, sedang dan rendah serta darigender laki-laki dan perempuan serta apakah kemampuan pemecahan masalah matematis siswa laki-laki lebih tinggi daripada perempuan.

Tabel 2. Hasil uji hipotesis tes kemampuan pemecahan masalah matematis.

\begin{tabular}{ccccccc}
\hline & \multicolumn{3}{c}{ Level Sekolah } & \multicolumn{3}{c}{ Gender } \\
\hline & Total & Tinggi & Sedang & Rendah & Laki-laki & Perempuan \\
\hline Asymp. Sig & 0,00 & 0,00 & 0,001 & 0,00 & 0,001 & 0,00 \\
\hline
\end{tabular}

Berdasarkan Tabel 2 diperoleh nilai signifikan kemampuan pemecahan masalah matematis siswa di MTsN sekabupaten Tanah Datar sebesar 0,00 maka dapat disimpulkan bahwa terdapat perbedaan nilai kemampuan pemecahan masalah matematis siswa yang diajar dengan model PBL dan konvensional di MTsN Kabupaten Tanah Datar. Hal ini didukung dari nilai rata-rata kemampuan pemecahan masalah matematis siswa sekolah level tinggi yang belajar menggunakan model PBL lebih baik dari pada siswa yang belajar secara konvensional. Selain itu, dapat pula dilihat nilai signifikan untuk level sekoah tinggi, sedang dan rendah serta untuk gender laki-laki dan perempuan juga diperoleh nilai sig.> 0,05 maka dapat disimpulkan bahwa terdapat perbedaan nilai kemampuan pemecahan masalah matematis siswa yang diajar dengan model PBL dan konvensional disekolah setiap level sekolah. 
DOI: https://doi.org/10.24127/ajpm.v10i1.2812
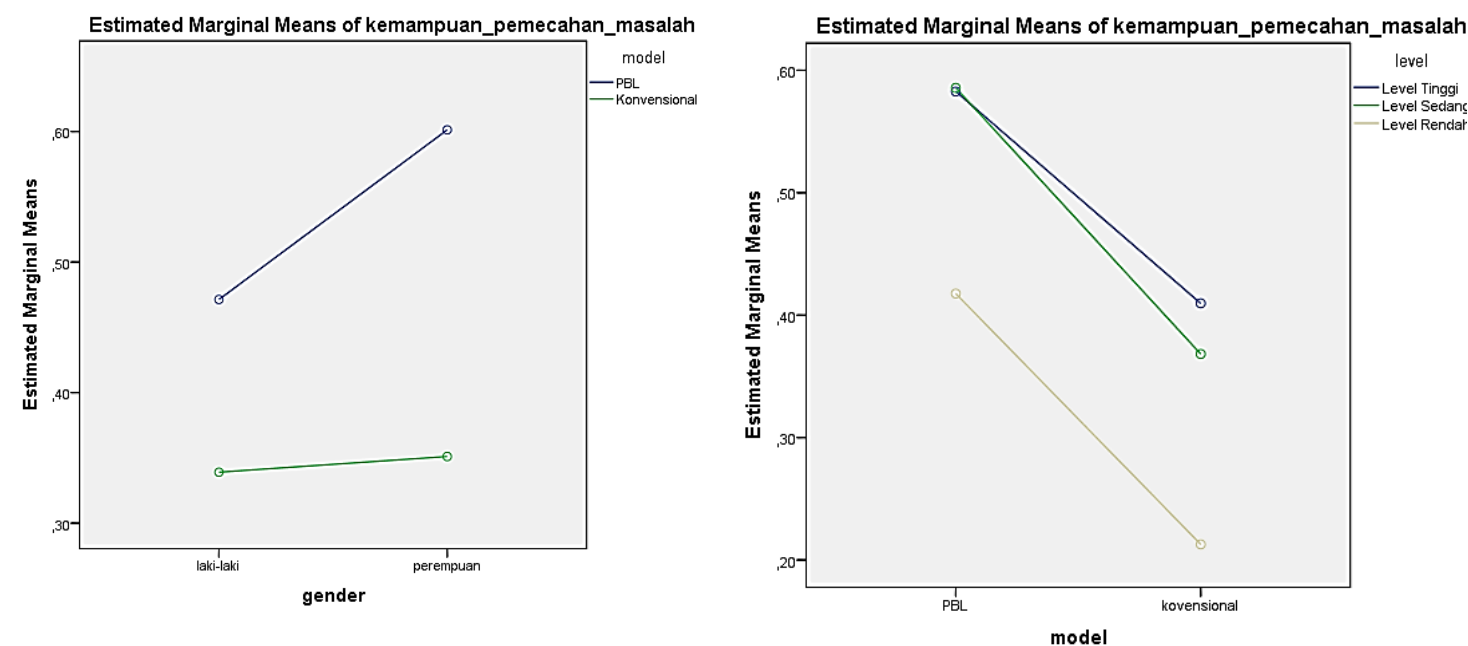

Gambar 1. Kemampuan pemecahan matematis ditinjau dari model pembelajaran dan gender/ level sekolah.

Berdasarkan Gambar 1 dapat disimpulkan bahwa tidak ada interaksi antara model pembelajaran dan gender dalam mempengaruhi kemampuan pemecahan masalah matematis siswa. Selain itu, dari grafik tersebut juga terlihat dalam hal kemampuan pemecahan masalah, pembelajaran dengan model PBL lebih efektif daripada pembelajaran konvensional baik bagi siswa laki-laki maupun perempuan. Dari Gambar 2 juga dapat dilihat bahwa tidak ada interaksi antara model pembelajaran dan level sekolah dalam mempengaruhi kemampuan pemecahan masalah matematis siswa.

Banyak hal yang menyebabkan keberhasilan suatu proses pembelajaran, satu diantaranya adalah penggunaan strategi pembelajaran di dalam proses pembelajaran. Tujuan strategi pembelajaran adalah menciptakan suatu bentuk pengajaran dengan kondisi tertentu untuk membantu proses belajar mengajar demi terciptanya pengajaran secara efektif, efisien dan penuh dengan daya tarik. PBL merupakan salah satu model yang bisa digunakan untuk keberhasilan suatu pembelajaran dimana PBL merupakan pembelajaran yang relevan dengan tuntutan abad ke21.

Kemampuan pemecahan masalah matematis siswa yang belajar dengan model PBL lebih tinggi dibandingkan dengan yang belajar dengan model konvensional. Penerapan model PBL mampu meningkatkan kemampuan pemecahan masalah matematis siswa dibandingkan dengan pembelajaran konvensional, hal ini juga ditemukan oleh beberapa peneliti sebelumnya yaitu Nadhifah \& Afriansyah (2016). Didukung juga oleh Warsono \& Hariyanto (2017) bahwa model PBL memilki kelebihan dimana dengan penerapan model PBL siswa akan terbiasa menghadapi masalah dan merasa tertantang untuk menyelesaikan masalah, tidak hanya terkait dengan pembelajaran dalam kelas, tetapi juga menghadapi masalah yang ada dalam kehidupan sehari-hari. Jadi dengan penerapan model PBL siswa akan terbiasa dalam memecahkan masalah sehingga model PBL mampu meningkatkan kemampuan pemecahan masalah matematis siswa.

Kemampuan pemecahan masalah matematis siswa yang belajar 
dengan model PBL lebih tinggi dibandingkan dengan yang belajar dengan model konvensional di sekolah level tinggi, sedang maupun rendah. Pembelajaran dengan model PBL sangat mempengaruhi terhadap kemampuan pemecahan masalah matematis siswa di setiap level sekolah, terlihat dari hasil yang lebih tinggi yang diperoleh oleh siswa kelas eksperimen dibandingkan kelas kontrol. Diantaranya seperti yang ditemukan oleh Sari dalam tulisannya pembelajaran matematika berbasis masalah dapat meningkatkan kemampuan pemecahan masalah matematis siswa.

Pembelajaran dengan model PBL yang berlandaskan masalahmasalah menuntut siswa mendapat pengetahuan yang penting, yang menjadikan mereka mahir dalam memecahkan masalah. Senada dengan itu menurut Arends menyatakan bahwa pembelajaran berbasis masalah dirancang untuk membantu siswa mengembangkan keterampilan berpikir, keterampilan menyelesaikan masalah, dan keterampilan intelektualnya (Sanusi Siregar, Surya, Syahputra, \& Rais Sirait, 2018). Oleh karena setiap pertemuan selalu ada masalah non rutin yang harus dipecahkan siswa, membuat siswa menjadi terlatih dan terbiasa menghadapi soal pemecahan masalah, sehingga kemampuan pemecahan masalah siswa menjadi lebih baik. Berbeda dengan hal tersebut penerapan pembelajaran dengan pendekatan konvensional untuk soal-soal pemecahan masalah baru mereka temui di akhir pembelajaran. Kurang banyaknya siswa terlibat dengan soal pemecahan masalah membuat kemampuan pemecahan masalah mereka tidak sebaik siswa yang belajar dengan model PBL.
Siswa yang belajar dengan model PBL menunjukkan penguasaan yang lebih baik pada semua indikator pemecahan masalah daripada siswa yang belajar secara konvensional. Keunggulan siswa yang belajar dengan model PBL jelas terlihat pada indikator mengorganisasi data dan memilih informasi yang relevan dalam mengidentifikasi masalah. Siswa yang belajar dengan pendekatan konvensional, kurang mampu dalam memilih informasi yang penting dan mengorganisasi informasi tersebut untuk menyusun strategi pemecahan masalah.

Kemampuan pemecahan masalah matematis siswa laki-laki yang belajar dengan model PBL lebih tinggi dibandingkan dengan yang belajar dengan model konvensional, hal ini berbeda dengan yang ditemukan oleh Widodo (Nur, Widodo, \& Amalia, 2020) tidak adanya perbedaan yang signifikan. Hal ini didukung oleh penelitian Eisenberg, Martin dan Fabes adanya temuan yang beragam dalam penelitian soal kemampuan matematika. Dalam beberapa analisis, anak laki-laki lebih bagus dalam matematika (Santrock, 2015). Pembelajaran dengan model PBL mempengaruhi kemampuan pemecahan masalah matematis siswa dengan gender laki-laki, salah satu karakteristik siswa laki-laki yang mendukung penerapan model PBL sehingga dapat meningkatkan kemampuan pemecahan masalah matematis dimana laki-laki memilki kelebihan penalaran yang abstrak, pengusaan matematik serta stuctural skills.

Kemampuan pemecahan masalah matematis siswa perempuan yang belajar dengan model PBL lebih tinggi dibandingkan dengan yang belajar dengan model konvensional. 
Pembelajaran dengan model PBL mempengaruhi kemampuan pemecahan masalah matematis siswa dengan gender perempuan, hal initerlihat dari hasil tes yang lebih tinggi yang diperoleh oleh siswa perempuan kelas eksperimen dibandingkan siswa perempuan kelas kontrol. Hal ini didukung oleh pendapat Surna dan Panderiot bahwa kemampuan membaca dan menulis peserta didik perempuan lebih menonjol serta peserta didik perempuan lebih giat belajar dan mampu mencapai prestasi belajar yang tinggi.

Kemampuan pemecahan masalah matematis siswa perempuan lebih tinggi dibandingkan dengan siswa laki-laki, hal tersebut juga ditemukan disetiap level sekolah. Tingginya kemampuan pemecahan masalah matematis perempuan daripada laki-laki ini tidak sejalan dengan teori dan juga penelitian terdahulu diantaranya menurut Santrock (Santrock, 2015) menyatakan bahwa anak laki-laki lebh bagus dalam matematika. Hal tersebut didukung oleh hasil temuan Anggraini bahwa kemampuan pemecahan masalah matematis laki-laki lebih baik daripada perempuan. Perbedaan yang terjadi antara teori dengan kenyataan yang ditemukan dilapangan diindikasikan terjadi karena peserta didik perempuan lebih giat belajar sehingga mampu mencapai prestasi belajar yang lebih tinggi dibandingkan laki-laki serta peserta didik perempuan lebih mampu berkonsentrasi dalam belajar dan berpartisipasi aktif dalam kelas.

Tidak terdapat interaksi antara model pembelajaran dan gender dalam mempengaruhi kemampuan pemecahan masalah matematis siswa. Model PBL dan konvensional tidak memberikan pengaruh kepada siswa dengan gender laki-laki dan perempuan dari segi kemampuan pemecahan masalah matematis.

Kemampuan pemecahan masalah siswa laki-laki dan perempuan yang belajar dengan model PBL dan konvensional memberikan hasil yang tidak jauh berbeda. Hal ini bertentangan dengan teori pada umumnya yaitu seperti yang dikemukakan oleh Anggraini, kemampuan pemecahan masalah matematika laki-laki lebih baik dari pada perempuan pada soal kontekstual dan juga ditemukan yaitu laki-laki secara konsisten melaporkan persepsi yang sedikit lebih positif dari lingkungan kelas dibandingkan dengan perempuan. Perbedaan yang terjadi antara teori dengan kenyataan yang ditemukan dilapangan terjadi karena peserta didik perempuan lebih giat belajar dan berpartisipasi aktif dalam kelas, sehingga dengan penerapan model PBL siswa perempuan mampu mengimbangi kemampuan laki-laki. Pernyataan ini didukung oleh Purwaningsih dan Ardani (Purwaningsih \& Ardani, 2020) bahwa setiap siswa dapat menyelesaikan permasalahan pada suatu persoalan matematika dengan kemampuan yang dimilkinya.

Tidak terdapat interaksi antara model pembelajaran dan level sekolah dalam mempengaruhi kemampuan pemecahan masalah matematis siswa. Tidak adanya interaksi ini berarti bahwa efek model PBL terhadap kemampuan pemecahan masalah matematis siswa tidak tergantung pada level sekolah. Pernyataan tersebut bertentangan dengan pendapat Fachrurazi (2011) bahwa siswa dari sekolah level tinggi memperoleh peningkatan yang lebih baik dibandingkan siswa yang berasal dari level sedang dan kurang dan siswa dari level sedang lebih baik dari level kurang. Hal ini membuktikan bahwa 
model PBL cocok serta mampu meningkatkan kemampuan pemecahan masalah matematis peserta didik disetiap level sekolah. Perbedaan antara teori dan kenyataan dilapangan terjadi karena model PBL merupakan model yang Dimana menurut Tan (Cahyani \& Setyawati, 2016) pembelajaran berbasis masalah merupakan pembelajaran yang relevan dengan tuntutan abad ke-21. Pembelajaran berbasis masalah merupakan inovasi dalam pembelajaran karena dalam pembelajarran berbasis masalah kemampuan berpikir siswa betul-betul dioptimalisasikan melalui proses kerja kelompok atau tim yang sistematis, sehingga siswa dapat memberdayakan, mengasah, menguji, dan mengembangkan kemampuan berpikirnya secara berkesinambungan.

\section{KESIMPULAN DAN SARAN}

Kemampuan pemecahan masalah matematis siswa yang belajar dengan model PBL lebih tinggi dibandingkan dengan yang belajar dengan model konvensional disekolah level tinggi, sedang dan rendah. Selanjutnya, kemampuan pemecahan masalah matematis siswa laki-laki ataupun perempuan yang belajar dengan model PBL juga lebih tinggi dibandingkan dengan yang belajar dengan model konvensional. Disamping itu, kemampuan pemecahan masalah matematis siswa laki-laki tidak lebih baik daripada perempuan dilevel sekolah tinggi, sedang dan rendah. Disisi lain tidak terdapat interaksi antara model pembelajaran dan gender dalam mempengaruhi kemampuan pemecahan masalah matematis siswa begitupun dengan level sekolah.

\section{DAFTAR PUSTAKA}

Ajai, J. T., \& Imoko, B. I. (2015). Gender differences in mathematics achievement and retention scores:
A case of problem-based learning method. International Journal of Research in Education and Science, 1(1), 45-50. https://doi.org/10.21890/ijres.7678 5

Cahyani, H., \& Setyawati, R. W. (2016). Pentingnya Peningkatan Kemampuan Pemecahan Masalah Melalui PBL untuk Mempersiapkan Generasi Unggul Menghadapi MEA. PRISMA, Prosiding Seminar Nasional Matematika, 151-160.

Darma, I. K., Candiasa, I. M., Sadia, I. W., \& Dantes, N. (2018). The effect of problem based learning model and authentic assessment on mathematical problem solving ability by using numeric ability as the covariable. Journal of Physics: Conference Series, 1040(1). https://doi.org/10.1088/17426596/1040/1/012035

Darmawan, A. (2018). Application of Problem Based Learning Model Assisted by Cabri Software to Improve Problem Solving Ability of Mathematics Students. Annual International Seminar on Transformative Education and Educational Leadership (AISTEEL) EISSN:, 437-440.

Dela Cruz, J. K. B., \& Lapinid, M. R. C. (2014). Students' Difficulties in Translating Worded Problems into Mathematical Symbols. DLSU Research Congress 2014, 1-7. Retrieved from www.dlsu.edu.ph/conferences/dlsu _research_congress/2014/_.../LLII-009-FT.pdf\%0A

Eviyanti, C. Y., Surya, E., Syahputra, E., \& Simbolon, M. (2017). Improving the Students' Mathematical Problem Solving Ability by Applying Problem 
Based Learning Model in VII Grade at SMPN 1 Banda Aceh Indonesia. International Journal of Novel Research in Education and Learning, 4(2), 138-144. Retrieved from

https://www.researchgate.net/publi cation/318529138

Fachrurazi. (2011). Penerapan Pembelajaran Berbasis Masalah Untuk Meningkatkan Kemampuan Berpikir Kritis Dan Komunikasi Matematis Siswa Sekolah Dasar. Jurnal Penelitian Pendidikan UPI, Edisi Khus(1), 76-89. Retrieved from

http://jurnal.upi.edu/penelitianpendidikan/view/637/

Febriana, R., Yusri, R., \& Delyana, H. (2020). Modul Geometri Ruang Berbasis Problem Based Learning Terhadap Kreativitas Pemecahan Masalah. AKSIOMA: Jurnal Program Studi Pendidikan Matematika, 9(1), 93. https://doi.org/10.24127/ajpm.v9i1. 2591

Hendriana, H. (2018). Hard Skills dan Soft Skills Matematis Siswa (Vol. 5). Bandung: PT. Refika Aditama.

Maharani, A., Darhim, D., Sabandar, J., \& Herman, T. (2018). Menumbuhkan Kemampuan Disposisi Matematis Melalui PBLTeam Teaching. JNPM (Jurnal Nasional Pendidikan Matematika), 2(2), 197. https://doi.org/10.33603/jnpm.v2i2 .840

Murtiyasa, B., \& Wulandari, V. (2020). Analisis Kesalahan Siswa Materi Bilangan Pecahan Berdasarkan Teori Newman. AKSIOMA: Jurnal Program Studi Pendidikan Matematika, 9(3), 713. https://doi.org/10.24127/ajpm.v9i3. 2795
Nadhifah, G., \& Afriansyah, E. A. (2016). Peningkatan kemampuan pemecahan masalah matematis siswa dengan menerapkan model pembelajaran problem based learning dan inquiry. Mosharafa: Jurnal Pendidikan Matematika, 5(1), 33-44. Retrieved from http://emosharafa.org/index.php/mosharaf a/article/view/mv5n1_5/187

Nufus, H. (2017). Pengaruh Interaksi Pembelajaran dan Level Sekolah Terhadap Kemampuan Komunikasi Matematis Siswa. JPPM (Jurnal Pengabdian Dan Pemberdayaan Masyarakat), 10(1), 115-123.

Nur, A., Widodo, A., \& Amalia, S. R. (2020). Creative Problem Solving dan Resource Based Learning Terhadap Kemampuan Pemecahan Masalah Matematis Ditinjau dari Gender. AKSIOMA: Jurnal Program Studi Pendidikan Matematika, 9(1), 158-165.

Purwaningsih, D., \& Ardani, A. (2020). Kemampuan Pemecahan Masalah Matematis Materi Eksponen Dan Logaritma Ditinjau Dari Gaya Belajar Dan Perbedaan Gender. AKSIOMA: Jurnal Program Studi Pendidikan Matematika, 9(1), 118. https://doi.org/10.24127/ajpm.v9i1. 2632

Santrock, J. (2015). Psikologi Pendidikan. In Kencana. https://doi.org/10.1115/83-gt-165 Sanusi Siregar, A., Surya, E., Syahputra, E., \& Rais Sirait, A. (2018). The Improving Mathematical Communication Ability and Students' SelfRegulation Learning through Realistic Mathematical Approach Based on Batak Toba Culture. American Journal of Educational 
DOI: https://doi.org/10.24127/ajpm.v10i1.2812

Research, 6(10), 1397-1402. https://doi.org/10.12691/education6-10-9

Warsono, \& Hariyanto. (2017). Pembelajaran Aktif. In Remaja Rosdakarya. Retrieved from https://ci.nii.ac.jp/naid/400212432 $59 /$

Ajai, J. T., \& Imoko, B. I. (2015). Gender differences in mathematics achievement and retention scores: A case of problem-based learning method. International Journal of Research in Education and Science, 1(1), 45-50. https://doi.org/10.21890/ijres.7678 5

Cahyani, H., \& Setyawati, R. W. (2016). Pentingnya Peningkatan Kemampuan Pemecahan Masalah Melalui PBL untuk Mempersiapkan Generasi Unggul Menghadapi MEA. PRISMA, Prosiding Seminar Nasional Matematika, 151-160.

Darma, I. K., Candiasa, I. M., Sadia, I. W., \& Dantes, N. (2018). The effect of problem based learning model and authentic assessment on mathematical problem solving ability by using numeric ability as the covariable. Journal of Physics: Conference Series, 1040(1). https://doi.org/10.1088/17426596/1040/1/012035

Darmawan, A. (2018). Application of Problem Based Learning Model Assisted by Cabri Software to Improve Problem Solving Ability of Mathematics Students. Annual International Seminar on Transformative Education and Educational Leadership (AISTEEL) EISSN:, 437-440.

Dela Cruz, J. K. B., \& Lapinid, M. R. C. (2014). Students' Difficulties in
Translating Worded Problems into Mathematical Symbols. DLSU Research Congress 2014, 1-7. Retrieved from www.dlsu.edu.ph/conferences/dlsu _research_congress/2014/_.../LLII-009-FT.pdf\%0A

Eviyanti, C. Y., Surya, E., Syahputra, E., \& Simbolon, M. (2017). Improving the Students' Mathematical Problem Solving Ability by Applying Problem Based Learning Model in VII Grade at SMPN 1 Banda Aceh Indonesia. International Journal of Novel Research in Education and Learning, 4(2), 138-144. Retrieved from

https://www.researchgate.net/publi cation/318529138

Fachrurazi. (2011). Penerapan Pembelajaran Berbasis Masalah Untuk Meningkatkan Kemampuan Berpikir Kritis Dan Komunikasi Matematis Siswa Sekolah Dasar. Jurnal Penelitian Pendidikan UPI, Edisi Khus(1), 76-89. Retrieved from

http://jurnal.upi.edu/penelitianpendidikan/view/637/

Febriana, R., Yusri, R., \& Delyana, H. (2020). Modul Geometri Ruang Berbasis Problem Based Learning Terhadap Kreativitas Pemecahan Masalah. AKSIOMA: Jurnal Program Studi Pendidikan Matematika, 9(1), 93. https://doi.org/10.24127/ajpm.v9i1. 2591

Hendriana, H. (2018). Hard Skills dan Soft Skills Matematis Siswa (Vol. 5). Bandung: PT. Refika Aditama. Maharani, A., Darhim, D., Sabandar, J., \& Herman, T. (2018). Menumbuhkan Kemampuan Disposisi Matematis Melalui PBLTeam Teaching. JNPM (Jurnal 
DOI: https://doi.org/10.24127/ajpm.v10i1.2812

Nasional Pendidikan Matematika), 2(2), 197. https://doi.org/10.33603/jnpm.v2i2 .840

Murtiyasa, B., \& Wulandari, V. (2020). Analisis Kesalahan Siswa Materi Bilangan Pecahan Berdasarkan Teori Newman. AKSIOMA: Jurnal Program Studi Pendidikan Matematika, 9(3), 713. https://doi.org/10.24127/ajpm.v9i3. 2795

Nadhifah, G., \& Afriansyah, E. A. (2016). Peningkatan kemampuan pemecahan masalah matematis siswa dengan menerapkan model pembelajaran problem based learning dan inquiry. Mosharafa: Jurnal Pendidikan Matematika, 5(1), 33-44. Retrieved from http://e-

mosharafa.org/index.php/mosharaf a/article/view/mv5n1_5/187

Nufus, H. (2017). Pengaruh Interaksi Pembelajaran dan Level Sekolah Terhadap Kemampuan Komunikasi Matematis Siswa. JPPM (Jurnal Pengabdian Dan Pemberdayaan Masyarakat), 10(1), 115-123.

Nur, A., Widodo, A., \& Amalia, S. R. (2020). Creative Problem Solving dan Resource Based Learning Terhadap Kemampuan Pemecahan
Masalah Matematis Ditinjau dari Gender. AKSIOMA: Jurnal Program Studi Pendidikan Matematika, 9(1), 158-165.

Purwaningsih, D., \& Ardani, A. (2020). Kemampuan Pemecahan Masalah Matematis Materi Eksponen Dan Logaritma Ditinjau Dari Gaya Belajar Dan Perbedaan Gender. AKSIOMA: Jurnal Program Studi Pendidikan Matematika, 9(1), 118. https://doi.org/10.24127/ajpm.v9i1. 2632

Santrock, J. (2015). Psikologi Pendidikan. In Kencana. https://doi.org/10.1115/83-gt-165

Sanusi Siregar, A., Surya, E., Syahputra, E., \& Rais Sirait, A. (2018). The Improving Mathematical Communication Ability and Students' SelfRegulation Learning through Realistic Mathematical Approach Based on Batak Toba Culture. American Journal of Educational Research, 6(10), 1397-1402. https://doi.org/10.12691/education6-10-9

Warsono, \& Hariyanto. (2017). Pembelajaran Aktif. In Remaja Rosdakarya. Retrieved from https://ci.nii.ac.jp/naid/400212432 $59 /$ 